\title{
Progress on Technology Use in
}

\section{Tourism}

\begin{abstract}
Purpose: With the rapid development and implementation of cutting-edge information technologies in tourism and hospitality, it is necessary to update the progress of technology use in the past 18 years and set up research agenda for future research. Adopting Information Systems (IS) as a reference discipline, this article aims to create a literature review of technology and tourism papers around the theme of use.
\end{abstract}

Design/methodology/approach: Following the systematic literature review process of Aguinis et al. (2018), 314 papers were downloaded to determine how they applied the concept of technology use.

Findings: Three themes about technology use emerged: types of processing, organisational use, and users. Among various types of technology processing, interactive and online are largely addressed in the tourism and hospitality literature. The organisational use theme explores how the competitive and strategic use of technology provides management support for organisations. There was a large amount of research focussed on direct users, such as individual characteristics, user attitudes, and user behaviour. The theories of TAM and UTAUT have been widely applied in these studies.

Originality/value: This paper provides a review of key issues which has been discussed in tourism research in relation to technology use. By applying the scheme developed in the IS discipline, this study provides new insights into the development of technology in tourism. In addition, it also gives us the opportunity to suggest a research agenda by identifying research gaps and future research collaboration opportunities between these two fields.

Keywords: processing, users, organisational, information systems, tourism, technology use

Article Classification: Literature Review

\section{Introduction}

Information technology use is one of the most explored areas in tourism technology since the $1980 \mathrm{~s}$ (Buhalis and Law, 2008). With the rapid development and implementation of cutting-edge information technologies in tourism and hospitality, it is necessary to update the progress of technology use in Tourism in the past 15 years, and set up research agenda for future research. In the past 18 years, there have been other review articles in a similar vein carried out (Buhalis and Law, 2008, Law et al., 2009, Daniel Leung et al., 2013, Navío-Marco et al., 2018). While some reviews 
focus on the specific use of mobile technology and social media in the tourism industry (Liang et al., 2017, Daniel Leung et al., 2013) others provide a more generic overview of the advancement of eTourism in this timeframe (Buhalis and Law, 2008, Navío-Marco et al., 2018). In contrast to these review papers, our paper specifically focusses on the technology use in tourism. Technology use has been recently touted as among the most central constructs in the Information System (IS) discipline (Straub and del Guidice, 2012). Subsequently, we believe a similar approach can be taken from a tourism technology perspective. Adopting IS as a reference discipline (Baskerville and Myers, 2002) enables a rigorous and comprehensive understanding of the progress on tourism technology use. Therefore, in this article, we aim to create a literature review of technology and tourism around the theme of use. The next section introduces the systematic literature review process followed in this research. The subsequent sections outline the key findings of the literature review process. Finally, the conclusion summarises the key research gaps and suggests opportunities for future research.

\section{Methodology}

We followed the systematic literature review process of Aguinis et al. (2018) as detailed below.

\section{Step 1: Determine Goal and Scope of Review}

The aim of this literature review focuses on the technology use, which has been recently touted as among the most central constructs in the Information System (IS) discipline (Straub and del Guidice, 2012). We apply this in the context of tourism research.

\section{Step 2: Determine Procedure to Select Journals Considered for Inclusion}

We downloaded papers from the following journals: Journal of Travel Research (JTR), Tourism Management (TM), Annals of Tourism Research (ATR), and the Journal of Sustainable Tourism (JST), These tourism journals were selected based on their high rankings (4* Academic Journal Guide 2018) within the Association of Business School's (ABS) journal rankings. We also selected two key specialised technology and tourism journals, the Journal of Hospitability and Tourism Technology (JHTT) and Information Technology \& Tourism (ITT). We also reviewed 6 review papers in this domain.

We downloaded papers based on a keyword search of "technology" within the title, abstract, or keywords for each journal using Scopus. We acknowledge that this keyword search may not retrieve all relevant papers, but it is the most widely used keyword and is often part of other terms such as "Information and Communication Technology". Using this keyword also provided a more manageable sample. We downloaded papers from the years 2000 to October 2018 from Scopus (to ensure the most current research was included). The total number of papers downloaded for each journal is illustrated in table 1. 
$<<$ Table 1 to appear about here $>>$

\section{Step 3: Calibrate Source Selection Process through Inter-coder Agreement}

Downloaded articles were then imported into NVivo for analysis. We ran a keyword query of the papers using the 'use' keyword list from Barki et al. (1993) and use terminology from (Burton-Jones et al., 2017). Based on the keywords discovered by the query, we then manually checked to see if the keyword was used in the correct context. If the context was incorrect, then the paper was disregarded. The authors discussed the keywords and the context to ensure that we were in agreement for a paper to be included or disregarded. The list of keywords used, and the number of codes matched to them, can be found in the appendix.

\section{Step 4: Select Sources using Process Identified in Step Three}

Each author took a sub-section of the keyword list and reviewed all papers within that section across all years and all journals:

- Author 1: Organizational Use of IS

- Author 2: Type of Support, Type of Processing

- Author 3: Users

Note: our keyword query did not find any papers from the sub-section Type of IS Access.

\section{Step 5: Calibrate Content Extraction Process through Inter-coder Agreement}

All authors read samples of the other authors' codes and discussed and compared notes from the selected articles, and to ensure that we addressed the evidence of our codes within the correct context.

\section{Step 6: Extract Relevant Content using Multiple Coders}

Each author read the full text of each paper coded within their sub-section and made notes about how to ensure the code was being used correctly. Based on themes emerging from the coding process, each author re-structured and grouped their codes to ensure papers with a similar context and code were considered together. For example, we found that some papers within the 'Type of Support' category were better suited in the 'Organisational Use' or 'Users' category, based on the focus of each paper. All authors then reviewed the coding structure and agreed on the recommendations made by each author. All authors agreed on the common themes found in the paper and used this to structure the literature review.

\section{Type of Processing}

Information Systems can facilitate information processing, which includes data collection, processes for data analysis, knowledge transfer, and information display for organisations and consumers. In our 
sample, we found tourism papers predominantly explored this from an interactive, online and realtime processing perspective.

\subsection{Interactive}

Interaction, among other factors, is an important issue for tourism, for example, e-commerce hotel bookings (Bilgihan et al., 2014), and social media marketing efforts (Tatar and Eren-Erdoğmuş, 2016). In an early study of the use of the Internet in travel agents, Buhalis and Licata (2002) argued that tourism intermediaries must reengineer their business processes to remain competitive. Many of the studies examined interactivity from a tourism marketing perspective. Özturan and Roney (2004) examined the Internet use of travel agencies in Turkey, and found that their websites did not have the interactive features required for Internet marketing. Young Chung et al. (2011) explored the use of interactive thematic maps on tourist perceptions, using a network analysis. They found that interactive maps can play an important role in tourists' planning behaviour, and for online tourism marketing. Online interactive processing of information as used by marketers can also apply to other technologies such as virtual worlds used for building destination images (Yu-Chih Huang et al., 2013), or to knowledge-based network participation in destination and event marketing (Breukel and Go, 2009). Interactive reservations received through direct channels and online travel agencies, cause tourism service providers to interface with new intermediaries (Digiorgio, 2016), while smart tourism destinations improve the co-creation of tourism experiences, and encourages greater interaction with tourists, and sharing of experiences (Buonincontri and Micera, 2016).

Other uses of interactivity were studied by image research and mobile devices. From the differences and commonalities between images of destinations, Govers et al. (2007) presented an interactive measurement approach for image research. From a study of mobile device use in private clubs, Morosan and DeFranco (2014) linked club members' demographic and behavioural characteristics to their use of mobile devices in clubs. There were a number of differences between the types of clubs, as well as the origins of the participants. More recent studies of interactivity have focussed on interactive decision-making tasks to find a destination to travel as a group (Delic et al., 2018), and the impact of digital technology on public governance processes for destination management (Kalbaska et al., 2017).

\subsection{Online}

Online was by far the most common type of processing in our sample, and from a very wide range of topics. We were able to categorise our sample into further, but related, categories:

Information sharing - in the earliest research, electronic word of mouth (eWoM) was considered as a cost-effective means for tourism and hospitality marketing, but ethical issues must be considered to engage with eWoM technologies (Litvin et al., 2008). However, it is useful for targeting new 
customers and planning effective marketing strategies (Rong et al., 2012). User-generated content (UGC) has increasingly been considered a credible form of eWoM (Stepchenkova and Zhan, 2013), and the sharing of videos has become more popular as a means to mediate tourist experiences (Tussyadiah and Fesenmaier, 2009). Photos are also a popular means of information sharing. People who post photos online tend to have higher incomes, are better educated, and from younger generations (Lo et al., 2011). Other forms of UGC include blogs, which can be used to help build a destination image (Tseng et al., 2015). Online information sharing can also be considered to model behavioural intentions to follow online travel advice from online communities (Lee and Hyun, 2015). These sources of information online can be further categorised in terms of specialization, endorsement, and other users' star ratings (Choi et al., 2018). Two other examples of information sharing in tourism focussed on interoperability solutions for online tourism distribution (Reino et al., 2016), and the effect of management response in engaging customers (Chunyu Li et al., 2017).

Information gathering - initial research of technology use in tourism focussed around the apprehension toward Internet use (Susskind et al., 2003) for gathering information for tourism purposes, i.e. trip planning. In 2005, an analysis was completed to understand how information search for travel information behaviours evolved (Beldona, 2005). Earlier research also focussed on the accessibility of information online for disabled tourists (Shi, 2006), and how to identify the challenges and potential solutions for online marketing of travel destinations (Xiang et al., 2008). Another stream of research focused on the representation of information online and the understanding of travellers' information needs as expressed through search engine queries (Xiang et al., 2009), and the effects that online information search had on tourists' destination image development (Xiang Li et al., 2009), destination image formation (Llodrà-Riera et al., 2015), and how tourists' search for information through alternative channels for more authentic and profound experiences (Xiang et al., 2015). More specific types of information are also sought, for example for the promotion of sustainable tourism for visiting world heritage sites (Garbelli et al., 2017), and for exchanges between hosts and guests in the sharing economy, for example couchsurfing (Germann Molz, 2013). While all of these studies focussed on the tourist or manager perspective, one study focused on the gathering of information by using advanced information technology for fire detection systems for protecting cultural heritage tourism resources (Joo et al., 2009).

Websites - an important tool related to information sharing and information gathering is the website. We found examples of tourism research from our sample which specifically discussed issues relating to the influence of website characteristics for planning a trip, (Kaplanidou and Vogt, 2006), how the design of a hotel website influences appeal and likelihood to purchase (Bender Stringam and Gerdes Jr, 2010), and how tourism websites influence consumer innovativeness for information search, purchasing, and communication (Couture et al., 2015). 


\subsection{Real Time}

Real time processing is another, although less researched area of technology use in tourism, but is an important issue, especially regarding the use of mobile travel services (Bouwman et al., 2011). From the perspective of creative tourism, Ihamäki (2012) explored the use of geocaching in adventure tourist destinations, and provided broader implications for adventure tourism. Joo et al. (2009) examined a real time fire detection system for protecting cultural heritage resources. Daigle and Zimmerman (2004) described visitor characteristics using real time bus information, to address transportation problems. Zheng et al. (2017) focussed on the prediction of a tourists' next location using GPS. Their research contributes towards tourist attraction administration and real time crowd control. Recognising the importance of this area, Hardy et al. (2017) developed a methodological approach for tracking tourists' movements through smartphones and global positioning systems.

\section{Organisational Use}

Recently, a paper manifesto arising out of a JITT conference identified pivotal research topics in eTourism (Werthner et al., 2015), in this paper the authors paid special attention to the increasing strategic use of ICTs in Tourism. For this reason, in this paper, we also include organisational use of IT as one of our key topic areas. From our analysis of the organisational use of IS, we found research relating to support, competitive IS and strategic IS. Organisations, regardless of the industry they operate in, their location or size, depend on the strategic use of IS to become and remain competitive. In particular, technology affects competitive advantage as it determines the relative cost position or differentiation of organisations (Buhalis, 1998, Arvidsson et al., 2014).

\subsection{Corporate or Management Support}

The number of papers which focussed on corporate support or management support for ICT was sparse, and from a wide range of technologies and domains. Technology adoption that entails the commitment of substantial resources is typically viewed as a strategic decision by top management (Cheng and Lok, 2015). In their study, the authors found that the recognition of the ability of IT to generate revenue and reduce costs was vital before management support could be sought for any investment in new IT (Cheng and Lok, 2015). In a comparative study, Reino et al. (2011) found there were differences in inter-firm technology adoption in rural and urban accommodation establishments in Scotland. They use their study to theoretically explain different levels of adoption between the two settings. Additionally, from a corporate level of support, travel intermediaries can use ICT to maintain a competitive advantage, obtain information capabilities, and focus on their critical success factors to enhance travel supply chains through inter-organizational collaboration (Lin, 2016). In the food service industries, managers use multiple ICT innovations, and differing rates of diffusion stages than was previously thought. IT adoption and implementation in this industry also related to significantly sufficient capital (Fareed Ismail et al., 2013). Tourism managers may use Internet-based marketing 
decision support systems. The use of these systems is highly dependent on a manager's perceived ease of use, perceived usefulness, their experience in using similar systems, their attitude to ICT in general, and the complexity of the task and time pressures in the work environment (Woeber and Gretzel, 2000)

\subsection{Competitive IS}

There is a dual focus in the competitive use of IS, that of the enhancing the guest experience and of improving the revenue of tourism organisations through the more innovative use of technology.

In the first instance, Bilgihan and Wang (2016) interviewed vice presidents, CTO/CIOs of hotels, CEOs of hospitality technology vendors and academics who focus on hospitality technology research. They found that IT-induced competitive advantage is possible when hotels choose to integrate all the possible technologies in the organization with a harmony that creates synergy. Similarly, another study announces a paradigm shift away from away from management-facing technology to the new customer-facing technology, where the customer's expectation of technology is at the forefront (Anne Coussement and J. Teague, 2013). Another study examined the use of interactive mobile technologies in enhancing the experiential value of guests (Wendy Zhu and Morosan, 2014). Tajeddini and Trueman (2014) provided a slightly different view, they investigated the role that national culture can play in using innovative technologies to retain competitive advantages.

The uptake of e-commerce has been well accepted as a means of gaining competitive advantage in the tourism industry (Hong-bumm Kim et al., 2009, Tsai et al., 2005). In terms of new technologies enhancing competitiveness from a management perspective, Buhalis and Licata (2002) discussed how traditional eMediaries must reengineer their business processes in order to survive and remain competitive by embracing the 3 new ePlatforms - the Internet, interactive digital television and mobile devices. Similarly, Höpken et al. (2015) discuss a novel way to utilise business intelligence to increase the competitiveness of a Swedish mountain destination. Fevzi Okumus (2013) discussed how organizations can facilitate knowledge management (KM) and thus gain a competitive edge through information technology (IT) tools. In order to achieve this, hospitality organizations not only need to create a supportive organizational culture and structure, but also train and motivate their team members to manage knowledge through IT applications. Another study investigated how social networks can become the primary tool for promoting tourist destinations and reaching a wider range of potential visitors to create competitive advantage in the market (Di Pietro et al., 2012).

A study based in Taiwan found different types of travel operations have different evaluation considerations for an application service provider (ASP) adoption. Travel intermediaries can devote to their core competencies, and acquire information support services through an ASP. On the other hand, ASPs can use differentiation strategies and allocate limited resources by focusing on these critical success factors to enhance inter-organizational collaboration in the travel supply chain (Lin, 2016). 
Further studies focus rather more on more explanatory factors that relate to improving competitiveness, for example, why do tourist organisations adopt e-Marketing (El-Gohary, 2012), why are internet based marketing decision support systems successful (Woeber and Gretzel, 2000). Interestingly, the majority of these studies rely on the Technology Acceptance Model (Davis, 1989) to provide theoretical support for their studies.

\subsection{Strategic IS}

The continuing development and widespread adoption of information technology (IT) have deeply influenced the tourism and hospitality industry, especially on a strategic level (Tae Goo Kim et al., 2008, Garces et al., 2004).

Cabiddu et al. (2013) examined how IT enables value co-creation and strategic advantage in tourism and why some players appear to appropriate the value co-created in the partnership more successfully compared to others. Similarly, Buonincontri and Micera (2016) discuss how involving tourists as active co-creators of their own experiences has given rise to a new kind of destination, a smart tourist destination, where technologies are so embedded in all tourist experiences that leads to the increased competitiveness of the destination. The importance of maintaining a successful network of actors is important for this to occur, Breukel and Go (2009) suggested that modern ICT may offer support to establishing hospitality networks that shape a physical and virtual environment for the delivery of services to developing client demands. Some studies indicate the importance of using technologies in a strategic manner especially in terms of social media and online presence. For example, Xi Y Leung et al. (2017) and Wozniak et al. (2017) examined the importance of strategic social media message strategies while Baggio et al. (2011) focused on general online web presence strategies. Also important are other IT solutions such as the adoption of interoperability solutions for online tourism distribution (OTD) (Reino et al., 2016), the vast number of applications that near field communication technologies have for the tourism industry (Egger, 2013), the use of intelligent context-aware recommender system that takes into account temporal and social context in tour guide applications (Meehan et al., 2016) or the strategic use of Customer Relationship Management systems in tourism as a whole (Vogt, 2011, Mohammed et al., 2017).

The use of ICT to promote sustainable tourism has garnered some attention from scholars too (Ali and J. Frew, 2014, Garbelli et al., 2017, Isacsson and Gretzel, 2011, Ali and Frew, 2014). Ali and J. Frew (2014) talked about the ability of ICTs to provide novel ways of approaching marketing, energy monitoring, waste management, and communication for destinations, while Garbelli et al. (2017) suggested how ICTs could be used in order for a destination to offer a proper and complete online communication, to educate travellers about the several implications of being a WHS and about a sustainable and responsible behaviour in case they choose to visit it. Finally, Isacsson and Gretzel (2011) discuss how Facebook can be used to engage students in learning about sustainable tourism. 
On the other hand, we only found a few studies that looked at the use of ICTs for strategic purposes in destination marketing (Buhalis, 2000, Ali and Frew, 2014, Gon et al., 2016, Dickinger and Lalicic, 2016).

Another thread in this area of research was exploring what kind of firms are more likely to embrace different types of technology for strategic purposes. Spencer et al. (2012) explored the factors influencing the decision to engage in technology adoption in small owner-managed travel firms. ElGohary (2012) indicated that environmental pressures significantly affect the perceived benefits and barriers of e-commerce adoption, in addition to having an indirect effect on adoption behaviour in tourism SME's in developing countries. Siguaw et al. (2000) concluded that luxury and upscale hotels adopted more IT than economy and budget hotels. Eugenia Ruiz-Molina et al. (2013) explored the use of ICTs in established and emerging tourist areas. They found that the reasons for making use of ICT may differ: while hotels located in established tourist destinations may use technology in order to differentiate themselves from the competition in the local market, hotels in emerging destinations may try to attract Western tourists who are looking for something different. Finally, Hsu et al. (2016) explored how established inbound tour operators (ITOs) are increasingly forced to embrace technology-enabled innovations to keep up with their increasingly digital savvy tourists.

Studies also found that the use of IT does not occur in a uniform manner, instead, there are different stages of adoption within organisations. For example, Yuan et al. (2006) found that advancements in IT in American convention and visitor bureaus did not spread uniformly across four information activity dimensions and appear to occur in five recursive and sequential stages, namely: substitution, enlargement, gestation, reconfiguration, and setback. Fareed Ismail et al. (2013) investigated how three organizational factors - affiliation, sufficient capital and company age - related to 323 Malaysian foodservice companies' diffusion of six information technology (IT) applications. Their study highlights multiple diffusion stages for multiple technological innovations in organisations.

\section{Users}

Information Systems are used by users at all levels of an organisation and can provide various types of support. There was a large amount of research focussed on users and sub-categories such as individual characteristics, user attitudes, user support, and end-user attitudes and behaviour.

\subsection{Individual Characteristics}

Studies find that individuals' backgrounds, demographic profiles and intentions largely determine the various patterns of technology use. Comparing the differences between travellers from Australia, China and the US in terms of technology readiness (TR) and customer satisfaction with travel technologies, Yi-Shun Wang et al. (2016) found out the relationships between perceived quality and satisfaction of technology-enabled services, overall satisfaction, and further behaviour were stronger 
among travellers with high TR and varied across countries. San Martín and Herrero (2012) found that the higher level of innovativeness of users, the more likely they purchase rural tourism products. Darley et al. (2017) investigated senior caravan travellers' characteristics and behaviours for SNS use in Australia.

Segmentations are proposed to develop a more strategic targeting plan in various contexts. Four user categories of mobile travel services were identified by Eriksson (2014) to provide insights for travel service providers. Lalicic and Weismayer (2016) categorised three types of tourists in terms of their emotional engagement with their mobile phones. Yuan et al. (2003) classified American convention and visitor bureaus into five adopter groups, and two paths of technology use. Morosan and DeFranco (2014) used actual mobile devices data to offer a systematic operationalization to distinguish private club members' behavioural and demographic characteristics in different types of clubs as well as different regions in the USA. Using cluster analysis, Lo et al. (2011) classified 5 cohorts of users in terms of different travel motivations, demographic profiles and the choice of online platforms to share travel photos. This finding provides implications for destination promotions.

\subsection{User expectations}

User expectations of technologies have been widely explored in various contexts. In the context of elearning in the tourism and hospitality course, students' expectations from Egypt are influenced by interpersonal, external and instructor these three social factors (Abbas, 2016). Some studies provide implications for organisations to meet users' expectations. By gaining emotional insights of passenger's airport experiences, Straker and Wrigley (2016) suggested airports can generate suitable digital channel engagement content to meet passengers' expectations. On a conceptual level, Coussement and Teague (2013) addressed the paradigm shift from management-facing technology to the new customer-facing technology in the hospitality industry. This helps the industry better manage customers' expectations by developing suitable mobile technologies.

Providers are required to integrate desirable features when developing new technologies to meet users' expectations. In the tourism and hospitality context, user requirements focus on conditions and criteria to develop new applications. Content requirement, functional requirement, comfort, experience and resistance are significant user requirement for developing the wearable AR museum application (tom Dieck et al., 2016). Given the heavy reliance of location-based recommendation in tour guide application, Meehan et al. (2016)'s study found that environmental, temporal and social these three contextual conditions at a significantly higher level of influence in mobile recommender systems. 


\subsection{User Support}

In terms of research into ICT from a perspective of user support, studies investigated the supportive role of interactive mobile technologies in hotel guests' facilitation of transactions. The adoption of these technologies can mediate the experiences of guests in hotel service settings, with importance placed on cognitive absorption, playfulness, and security (Wendy Zhu and Morosan, 2014). Virtual worlds, such as Second Life, can provide visual 3D representations of destinations, and have also been used in the travel and tourism industry for marketing tourism destinations, and business management. The experience and behavioural intentions of tourists' to use virtual worlds is related to positive emotions, enjoyment, emotional involvement, and flow experience. Social media sites also allow for visual representations of destinations through user-generated content such as the sharing of images. User-generated content has become a new and credible form of word of mouth, as tourists share their images and travel experiences with their social networks. The types of images uploaded by destination marketing organisations, when compared with those uploaded by users, can provide a useful means for tourists' destination image (Stepchenkova and Zhan, 2013). Ribeiro et al. (2018) explored the potential of mobile technologies can provide supports for disabled tourists to engage in tourist activities.

\subsection{End User Attitudes and Behaviours}

When looking at consumers, most studies focus on direct users and end users given the increasing user confidence and the improvement from providers. Influential factors of consumers' intentions and satisfaction were largely explored in the context of online reservation systems (Woo Gon Kim et al., 2006, San Martín and Herrero, 2012, Gregorash, 2016), firm-hosted online travel communities (Casaló et al., 2010), implementation of eVisa (Çakar et al., 2018), and registered traveller biometric system in air travel (Morosan, 2013). Other research has explored the factors affecting intentions for online purchasing generally (Amaro and Duarte, 2015), and more specifically the intentions of purchasing flights from low-cost carrier websites (Escobar-Rodríguez and Carvajal-Trujillo, 2014). Oppositely, Huertas (2018) and Dinhopl and Gretzel (2016) look at how the use of new technology (videos) influence and construct tourists' travel behaviour and experiences. Related to consumer behaviour, the idea of trust has been emphasised (Agag and El-Masry, 2017, Jungsun Kim et al., 2017) when perceiving new technologies. Content providers, such as tourism boards, are considered the able information providers, however, user-generated content appears to be the most trustworthy, although not necessarily the most informative (Dickinger, 2011).

Technology Acceptance Model (TAM) has been widely adopted to discuss users' attitudes and behavioural intention. It has been utilised as a theoretical construct to understand factors that influencing users' attitudes and intentions of technology use, such as the interrelationship of travellers' attitudes towards travel mobile applications with utilitarian and hedonic motivations, and 
self-identity (Young Im and Hancer, 2014), gender differences in terms of technology acceptance in the high-power conditions (Lu Zhang et al., 2014), factors that influence tourists' acceptance of mobile electronic tourist guides (METG). TAM also used as a useful model to explain why many customers not using mobile applications from the hospitality firms (Kwon et al., 2013).

Some studies extend and modify TAM with other variables and/or theories to investigate users' attitudes and behavioural intentions in their contexts. Balouchi et al. (2017) examined influences of TAM and variables of perceived enjoyment, perceived source credibility and perceived risk in the behavioural intention in accepting consumer generated contents (CGC) in the context of Iran. Park et al. (2014) looked at how franchise support, which is not included in the original TAM, affects attitudes towards franchise intranet usage in quick service restaurants (QSR). Straker and Wrigley (2016) developed the TAM by proposing to include emotional drivers as influences in the use of digital channels in their study of passengers' airport experience. Therefore, TAM has been widely extended with contextual factors to understand tourists' acceptance of social media for the choice of destination (Di Pietro et al., 2012), biometric systems (Morosan, 2012), consumer-generated media (CGM) usage for travel planning (Ayeh et al., 2013), and airline BC2 e-Commerce websites (Hongbumm Kim et al., 2009)

In some studies, TAM is combined with other theory (ies) to develop the theoretical framework. JenMin Huang et al. (2015) used TAM and readiness model as the research structure to investigate the user's intention golfers towards golf GPS. By examining the applicability of the TAM and Hedonic Theory, (Yu-Chih Huang et al., 2013) developed a research framework to identify the factors that affect tourists' experience and behavioural intentions within a 3D tourism destination. From a generational perspective, (Sox et al., 2016) synthesised a theoretical model of technology use within meetings by investigating how attendees' experiences and the basis of the Generational Cohort Theory (GCT) influence the TAM. Integrated TAM with the theory of reasoned action, the theory of planned behaviour, and the innovation diffusion theory, Amaro and Duarte (2015) proposed and test a model of consumers' intentions to purchase travel online. Casaló et al. (2010) provided a framework that integrates TAM with the Theory of Planned Behaviour and Social Identity Theory to explain the intention to participate in firm-hosted online travel communities.

The Unified Theory of Acceptance and Use of Technology (UTAUT) is another widely used theory in tourism technology research. UTAUT was developed by Venkatesh et al. (2003) to predict user adoption of an information technology. Venkatesh et al. (2003) found that performance expectancy, effort expectancy, social influence and facilitating conditions are the main factors determining user adoption. Escobar-Rodríguez and Carvajal-Trujillo (2014) applied an extended UTAUT model to examine key determinants of purchasing flights from low-cost carrier websites. San Martín and 
Herrero (2012) established a theoretical model that includes psychological factors that influence tourists' online purchase intention in rural tourism. Based on the UTAUT-2 framework, Gupta et al. (2018) found that performance expectancy, social influence, price saving, perceived risk, perceived trust and prior usage habits are significant predictors that affect tourists' intention of using travel apps.

Some studies synthesise new framework or theory to understand tourist behaviours of technology use. Dan Wang et al. (2014) proposed a new framework to understand the holistic understanding of smartphone use for travel that integrates the mechanism shaping the adoption, use and impact of smartphones. Tingting Zhang et al. (2015) proposed a conceptual model that suggest brand equity, sense of community and monetary incentive are three main motivations for customer engagement in online co-innovation communities (OCCs). In Dinhopl and Gretzel (2016)'s conceptual study, the theory of tourist videography was proposed to establish a foundation of various social practices in relation to tourists' video taking on holiday. Synthesising previous research, Bendegul Okumus and Bilgihan (2014) developed a conceptual model to test users' intention of using mobile applications as a tool to promote healthy eating in the restaurant.

\section{Discussion and Conclusion}

\subsection{Concluding thoughts}

In this paper, we adopt Barki et al. (1993)'s keyword classification scheme to provide a rigorous and comprehensive understanding of the progress on technology use in tourism. Around the theme of use, we found that research has been widely conducted in both organisational and individual levels with focuses in certain areas. In tourism and hospitality organisations, innovative technologies are used by managers as a strategic tool to maintain a competitive advantage, develop marketing strategies, or support their decision makings. In addition, the recent development of technology such as the interactive feature of the information technology, virtual world, and wearable AR applications also enable tourism and hospitality providers to design a wide range of experiences. One key goal of adopting new technologies is to achieve high levels of user satisfaction. A large amount of research focuses on the consumers, ranging from their expectation, attitudes and behaviours towards various forms of technologies in different tourism and hospitality settings. Among these, eWoM and mobile technologies have been largely explored (Munar and Jacobsen, 2014, Young Im and Hancer, 2014), given the increasing confidence of consumers as well as the development of ICT and e-platforms. Our findings are illustrated in figure 1. The figure is organised by major keyword themes. Bolded keywords above the line were found in our analysis, while un-bolded items below the line were missing from the literature. Based on the focus of the papers, we reclassified [User Support] and [Corporate or Management] research into different categories. Additionally, we found no research from the 'Type of Access' category. 
$<<$ Figure 1 to appear about here $>>$

\subsection{Theoretical Implications}

In terms of theories, information system theories such as UTAUT, TAM, Hedonic Theory, and Innovation Diffusions Theory are widely adopted or extended in various tourism and hospitality context to understand technology use. In addition to IS theories, these articles also widely adopt concepts from other fields and disciplines such as Cognitive Absorption, postcolonial theory and theory of tourist motivation, the theory of affordances and the theory of planned behaviour. Furthermore, there are several conceptual papers developing new frameworks and/or theories to understand technology use.

Future research can broaden the choice of IS theories. Two particular theories that could be borrowed from the information systems field is that of adaptive structuration theory (DeSanctis and Poole, 1994) and task-technology fit theory (Goodhue and Thompson, 1995). The basic reasoning of adaptive structuration theory is that of how information systems work. System designers embed their own intentions (spirit) into the functioning of the systems, but that users "adapt" these to their own needs (appropriations) and thus use the system in unintended ways (Straub, 2012). These kinds of workarounds result in new ways to use systems which designers respond to in subsequent redesigns. From a tourism information technology design point of view, this could be an interesting theory to apply in terms of how technology evolves over time according to use. On the other hand, the tasktechnology fit theory asserts that users, depending on the relevant tasks at hand, make conscious choices of best-fitting technologies before they use systems (Straub, 2012). Again this could be applied to the tourism field in terms of how and why users choose information systems for their specific purposes.

Studies of technology use can be further explored by exploring various critical turns of theories, such as mobilities turns, performance turn, late modernity and queer theory in order to contribute to critical tourism and hospitality studies. Issues such as the critics of ubiquitous connectivity during the holiday, ICT roles in the social inclusion in the holiday space, and ethical concerns the robotic use in the hospitality sector are worthy of further investigation.

\subsection{Practical Implications}

Our paper has delineated the research in this area into three main categories: type of processing, organisational use, and users. This is a useful way of categorising the main uses of technology in tourism. That is, managers for example, can and should deal with future IT-related issues by integrating the innovative uses of IT into their strategic business plans. One way to do this is to simultaneously be aware of changing IT technology that could benefit the bottom line of tourist organisations, and being aware of changing tourist perceptions, expectations and increasing digital 
savviness. The way data is collected, stored and analysed is also important to consider due to changes in data protection laws in Europe for example, and future research could explore more ways to make this interactive, online, and to provide information processing in real-time.

\subsection{Limitations and Future Research}

This literature review article focuses on four high impact tourism journals and two specialised tourism and technology journals. Although the selection criteria ensures the quality and impact of reviewed papers, some relevant research published in other journals or proceedings could be potentially excluded. Future research can review a wider scope of journals and books in order to achieve a comprehensive understanding. This article applied Barki et al. (1993)'s keyword classification scheme of IS use. In figure 1, we illustrate that tourism and technology studies only focus on certain use themes, and there are a wide range of themes in IS use which are under-researched. Tourism and IS academics can look for potential topics to research in these areas.

\section{References}

Abbas, T. (2016), "Social factors affecting students' acceptance of e-learning environments in developing and developed countries: A structural equation modeling approach", Journal of Hospitality and Tourism Technology, 7 (2), pp. 200-212.

Agag, G. M. and El-Masry, A. A. (2017), "Why do consumers trust online travel websites? Drivers and outcomes of consumer trust toward online travel websites", Journal of Travel Research, $56(3)$, pp. 347-369.

Aguinis, H. et al. (2018), "What you see is what you get? Enhancing methodological transparency in management research", Academy of Management Annals, 12 (1), pp. 83-110.

Ali, A. and Frew, A. J. (2014), "Technology innovation and applications in sustainable destination development", Information Technology \& Tourism, 14 (4), pp. 265-290.

Ali, A. and J. Frew, A. (2014), "ICT and sustainable tourism development: an innovative perspective", Journal of Hospitality and Tourism Technology, 5 (1), pp. 2-16.

Amaro, S. and Duarte, P. (2015), "An integrative model of consumers' intentions to purchase travel online", Tourism management, 46 64-79.

Anne Coussement, M. and J. Teague, T. (2013), "The new customer-facing technology: mobile and the constantly-connected consumer", Journal of Hospitality and Tourism Technology, 4 (2), pp. 177-187.

Arvidsson, V. et al. (2014), "Information systems use as strategy practice: A multi-dimensional view of strategic information system implementation and use", The Journal of Strategic Information Systems, 23 (1), pp. 45-61.

Ayeh, J. K. et al. (2013), "Predicting the intention to use consumer-generated media for travel planning", Tourism Management, 35 132-143.

Baggio, R. et al. (2011), "Technological aspects of public tourism communication in Italy", Journal of Hospitality and Tourism Technology, 2 (2), pp. 105-119.

Balouchi, M. et al. (2017), "Explaining and predicting online tourists' behavioural intention in accepting consumer generated contents", Journal of Hospitality and Tourism Technology, 8 (2), pp. 168-189.

Barki, H. et al. (1993), "A keyword classification scheme for IS research literature: An update", Mis Quarterly, 17 (2), pp. 209-226.

Baskerville, R. L. and Myers, M. D. (2002), "Information systems as a reference discipline", Mis Quarterly, 26 (1), pp. 1-14.

Beldona, S. (2005), "Cohort analysis of online travel information search behavior: 1995-2000", Journal of Travel Research, 44 (2), pp. 135-142. 
Bender Stringam, B. and Gerdes Jr, J. (2010), "Are pictures worth a thousand room nights? Success factors for hotel web site design", Journal of Hospitality and Tourism Technology, 1 (1), pp. $30-49$.

Bilgihan, A. et al. (2014), "Online experiences: flow theory, measuring online customer experience in e-commerce and managerial implications for the lodging industry", Information Technology \& Tourism, 14 (1), pp. 49-71.

Bilgihan, A. and Wang, Y. (2016), "Technology induced competitive advantage: a case of US lodging industry", Journal of Hospitality and tourism Technology, 7 (1), pp. 37-59.

Bouwman, H. et al. (2011), "Mobile Travel Services - The Effect of Moderating Context Factors", Information Technology \& Tourism, 13 (2), pp. 57-74.

Breukel, A. and Go, F. M. (2009), "Knowledge-based network participation in destination and event marketing: A hospitality scenario analysis perspective", Tourism Management, 30 (2), pp. 184-193.

Buhalis, D. (1998), "Strategic use of information technologies in the tourism industry", Tourism management, 19 (5), pp. 409-421.

Buhalis, D. (2000), "Marketing the competitive destination of the future", Tourism management, 21 (1), pp. 97-116.

Buhalis, D. and Law, R. (2008), "Progress in information technology and tourism management: 20 years on and 10 years after the Internet-The state of eTourism research", Tourism management, 29 (4), pp. 609-623.

Buhalis, D. and Licata, M. C. (2002), "The future eTourism intermediaries", Tourism management, 23 (3), pp. 207-220.

Buonincontri, P. and Micera, R. (2016), "The experience co-creation in smart tourism destinations: a multiple case analysis of European destinations", Information Technology \& Tourism, 16 (3), pp. 285-315.

Burton-Jones, A. et al. (2017), IS Use in MIS Quarterly Research Curations. Available at: http://misq.org/research-curations (Accessed: 29 July 2018).

Cabiddu, F. et al. (2013), "Managing value co-creation in the tourism industry", Annals of Tourism Research, 42 86-107.

Çakar, K. et al. (2018), "eVisa's impacts on travel and tourism: the case of Turkey", Journal of Hospitality and Tourism Technology, 9 (1), pp. 14-32.

Casaló, L. V. et al. (2010), "Determinants of the intention to participate in firm-hosted online travel communities and effects on consumer behavioral intentions", Tourism management, 31 (6), pp. 898-911.

Cheng, V. T. P. and Lok, P. (2015), "Strategic decision-making criteria and process of top management on technology adoption in the travel agency industry", Information Technology \& Tourism, 15 (3), pp. 189-208.

Choi, Y. et al. (2018), "Understanding the Sources of Online Travel Information", Journal of Travel Research, 57 (1), pp. 116-128.

Coussement, A. M. and Teague, J. T. (2013), "The new customer-facing technology: mobile and the constantly-connected consumer", Journal of Hospitality and Tourism Technology, 4 (2), pp. 177-187.

Couture, A. et al. (2015), "The influence of tourism innovativeness on online consumer behavior", Journal of Travel Research, 54 (1), pp. 66-79.

Daigle, J. J. and Zimmerman, C. A. (2004), "The convergence of transportation, information technology, and visitor experience at Acadia National Park", Journal of Travel Research, 43 (2), pp. 151-160.

Darley, T. et al. (2017), "Grey Nomads' caravanning use of social networking sites", Information Technology \& Tourism, 17 (4), pp. 379-398.

Davis, F. D. (1989), "Perceived usefulness, perceived ease of use, and user acceptance of information technology", MIS quarterly, 319-340.

Delic, A. et al. (2018), "An observational user study for group recommender systems in the tourism domain", Information Technology \& Tourism, 19 (1-4), pp. 87-116.

DeSanctis, G. and Poole, M. S. (1994), "Capturing the complexity in advanced technology use: Adaptive structuration theory", Organization science, 5 (2), pp. 121-147. 
Di Pietro, L. et al. (2012), "Social network for the choice of tourist destination: Attitude and behavioural intention", Journal of Hospitality and Tourism Technology, 3 (1), pp. 60-76.

Dickinger, A. (2011), "The trustworthiness of online channels for experience-and goal-directed search tasks", Journal of Travel Research, 50 (4), pp. 378-391.

Dickinger, A. and Lalicic, L. (2016), "An analysis of destination brand personality and emotions: a comparison study", Information Technology \& Tourism, 15 (4), pp. 317-340.

Digiorgio, V. (2016), "Impact of promotional tools on reservation channels management: a descriptive model of Italian accommodation facilities", Information Technology \& Tourism, 16 (4), pp. 347-373.

Dinhopl, A. and Gretzel, U. (2016), "Conceptualizing tourist videography", Information Technology \& Tourism, 15 (4), pp. 395-410.

Egger, R. (2013), "The impact of near field communication on tourism", Journal of Hospitality and Tourism Technology, 4 (2), pp. 119-133.

El-Gohary, H. (2012), "Factors affecting E-Marketing adoption and implementation in tourism firms: An empirical investigation of Egyptian small tourism organisations", Tourism management, 33 (5), pp. 1256-1269.

Eriksson, N. (2014), "User categories of mobile travel services", Journal of Hospitality and Tourism Technology, 5 (1), pp. 17-30.

Escobar-Rodríguez, T. and Carvajal-Trujillo, E. (2014), "Online purchasing tickets for low cost carriers: An application of the unified theory of acceptance and use of technology (UTAUT) model", Tourism Management, 43 70-88.

Eugenia Ruiz-Molina, M. et al. (2013), "The use of ICT in established and emerging tourist destinations: A comparative analysis in hotels", Journal of Hospitality and Tourism Technology, 4 (2), pp. 96-118.

Fareed Ismail, A. et al. (2013), "Information technology diffusion in Malaysia's foodservice industry", Journal of Hospitality and Tourism Technology, 4 (3), pp. 200-210.

Garbelli, M. et al. (2017), "Value perception of world heritage sites and tourism sustainability matters through content analysis of online communications: The case of Victoria Falls world heritage site", Journal of Hospitality and Tourism Technology, 8 (3), pp. 417-431.

Garces, S. A. et al. (2004), "Implications of the Internet-An analysis of the Aragonese hospitality industry, 2002", Tourism management, 25 (5), pp. 603-613.

Germann Molz, J. (2013), "Social networking technologies and the moral economy of alternative tourism: The case of couchsurfing.org", Annals of tourism research, 43 210-230.

Gon, M. et al. (2016), "Destination management organizations (DMOs) and Digital Natives: the neglected "informal expertise" in web 2.0 implementation and social media presence. Insights from the Italian Friuli Venezia Giulia DMO", Information Technology \& Tourism, 16 (4), pp. 435-455.

Goodhue, D. L. and Thompson, R. L. (1995), "Task-technology fit and individual performance", MIS quarterly, 213-236.

Govers, R. et al. (2007), "Virtual destination image a new measurement approach", Annals of Tourism Research, 34 (4), pp. 977-997.

Gregorash, B. J. (2016), "Restaurant revenue management: apply reservation management?", Information Technology \& Tourism, 16 (4), pp. 331-346.

Gupta, A. et al. (2018), "What determines tourist adoption of smartphone apps? An analysis based on the UTAUT-2 framework", Journal of Hospitality and Tourism Technology, 9 (1), pp. 50-64.

Hardy, A. et al. (2017), "Tracking tourists' travel with smartphone-based GPS technology: a methodological discussion", Information Technology \& Tourism, 17 (3), pp. 255-274.

Höpken, W. et al. (2015), "Business intelligence for cross-process knowledge extraction at tourism destinations", Information Technology \& Tourism, 15 (2), pp. 101-130.

Hsu, A. Y.-c. et al. (2016), "In-destination tour products and the disrupted tourism industry: progress and prospects", Information Technology \& Tourism, 16 (4), pp. 413-433.

Huang, J.-M. et al. (2015), "A discussion on the user intention of golfers toward golf GPS navigation", Journal of Hospitality and Tourism Technology, 6 (1), pp. 26-39.

Huang, Y.-C. et al. (2013), "Exploring user acceptance of 3D virtual worlds in travel and tourism marketing", Tourism Management, 36 490-501. 
Huertas, A. (2018), "How live videos and stories in social media influence tourist opinions and behaviour", Information Technology \& Tourism, 1-28.

Ihamäki, P. (2012), "Geocachers: The creative tourism experience", Journal of hospitality and tourism technology, 3 (3), pp. 152-175.

Isacsson, A. and Gretzel, U. (2011), "Facebook as an edutainment medium to engage students in sustainability and tourism", Journal of Hospitality and Tourism Technology, 2 (1), pp. 81-90.

Joo, J. et al. (2009), "Protecting cultural heritage tourism sites with the ubiquitous sensor network", Journal of Sustainable Tourism, 17 (3), pp. 397-406.

Kalbaska, N. et al. (2017), "When digital government matters for tourism: a stakeholder analysis", Information Technology \& Tourism, 17 (3), pp. 315-333.

Kaplanidou, K. and Vogt, C. (2006), "A structural analysis of destination travel intentions as a function of web site features", Journal of Travel research, 45 (2), pp. 204-216.

Kim, H.-b. et al. (2009), "Modeling roles of subjective norms and eTrust in customers' acceptance of airline B2C eCommerce websites", Tourism management, 30 (2), pp. 266-277.

Kim, J. et al. (2017), "Factors affecting customers' intention to use of location-based services (LBS) in the lodging industry", Journal of Hospitality and Tourism Technology, 8 (3), pp. 337-356.

Kim, T. G. et al. (2008), "An empirical examination of the acceptance behaviour of hotel front office systems: An extended technology acceptance model", Tourism management, 29 (3), pp. 500513.

Kim, W. G. et al. (2006), "Determinants of Chinese hotel customers'e-satisfaction and purchase intentions", Tourism Management, 27 (5), pp. 890-900.

Kwon, J. M. et al. (2013), "Mobile applications in the hospitality industry", Journal of Hospitality and Tourism Technology, 4 (1), pp. 81-92.

Lalicic, L. and Weismayer, C. (2016), "The passionate use of mobiles phones among tourists", Information Technology \& Tourism, 16 (2), pp. 153-173.

Law, R. et al. (2009), "Information technology applications in hospitality and tourism: a review of publications from 2005 to 2007", Journal of travel \& tourism marketing, 26 (5-6), pp. 599623.

Lee, K.-H. and Hyun, S. S. (2015), "A model of behavioral intentions to follow online travel advice based on social and emotional loneliness scales in the context of online travel communities: The moderating role of emotional expressivity", Tourism Management, 48 426-438.

Leung, D. et al. (2013), "Social media in tourism and hospitality: A literature review", Journal of travel \& tourism marketing, 30 (1-2), pp. 3-22.

Leung, X. Y. et al. (2017), "Hotel social media marketing: a study on message strategy and its effectiveness", Journal of Hospitality and Tourism Technology, 8 (2), pp. 239-255.

Li, C. et al. (2017), "The signaling effect of management response in engaging customers: A study of the hotel industry", Tourism Management, 62 42-53.

Li, X. et al. (2009), "The effect of online information search on image development: Insights from a mixed-methods study", Journal of Travel Research, 48 (1), pp. 45-57.

Liang, S. et al. (2017), "The relevance of mobile tourism and information technology: an analysis of recent trends and future research directions", Journal of Travel \& Tourism Marketing, 34 (6), pp. 732-748.

Lin, S.-W. (2016), "The critical success factors for a travel application service provider evaluation and selection by travel intermediaries", Tourism Management, 56 126-141.

Litvin, S. W. et al. (2008), "Electronic word-of-mouth in hospitality and tourism management", Tourism management, 29 (3), pp. 458-468.

Llodrà-Riera, I. et al. (2015), "A multidimensional analysis of the information sources construct and its relevance for destination image formation", Tourism management, 48 319-328.

Lo, I. S. et al. (2011), "Tourism and online photography", Tourism management, 32 (4), pp. 725-731.

Meehan, K. et al. (2016), "Aggregating social media data with temporal and environmental context for recommendation in a mobile tour guide system", Journal of Hospitality and Tourism Technology, 7 (3), pp. 281-299.

Mohammed, A. A. et al. (2017), "Customer relationship management and hotel performance: the mediating influence of marketing capabilities - evidence from the Malaysian hotel industry", Information Technology \& Tourism, 17 (3), pp. 335-361. 
Morosan, C. (2012), "Voluntary Steps toward Air Travel Security:An Examination of Travelers' Attitudes and Intentions to Use Biometric Systems", Journal of Travel Research, 51 (4), pp. 436-450.

Morosan, C. (2013), "An analysis of the relationship between travel preferences and intentions to use registered traveler biometric systems in air travel", Journal of Hospitality and Tourism Technology, 4 (1), pp. 23-39.

Morosan, C. and DeFranco, A. (2014), "Understanding the actual use of mobile devices in private clubs in the US", Journal of Hospitality and Tourism Technology, 5 (3), pp. 278-298.

Munar, A. M. and Jacobsen, J. K. S. (2014), "Motivations for sharing tourism experiences through social media", Tourism Management, 43 46-54.

Navío-Marco, J. et al. (2018), "Progress in information technology and tourism management: 30 years on and 20 years after the internet-Revisiting Buhalis \& Law's landmark study about eTourism", Tourism Management, 69 460-470.

Okumus, B. and Bilgihan, A. (2014), "Proposing a model to test smartphone users' intention to use smart applications when ordering food in restaurants", Journal of Hospitality and Tourism Technology, 5 (1), pp. 31-49.

Okumus, F. (2013), "Facilitating knowledge management through information technology in hospitality organizations", Journal of Hospitality and Tourism Technology, 4 (1), pp. 64-80.

Özturan, M. and Roney, S. A. (2004), "Internet use among travel agencies in Turkey: an exploratory study", Tourism Management, 25 (2), pp. 259-266.

Park, K. et al. (2014), "Exploring the impact of franchise support on franchisee acceptance of intranet in quick service restaurant (QSR) franchise system", Journal of Hospitality and Tourism Technology, 5 (2), pp. 143-159.

Reino, S. et al. (2016), "Adopting interoperability solutions for online tourism distribution: An evaluation framework", Journal of Hospitality and Tourism Technology, 7 (1), pp. 2-15.

Reino, S. et al. (2011), "ICT adoption and development: issues in rural accommodation", Journal of Hospitality and Tourism Technology, 2 (1), pp. 66-80.

Ribeiro, F. R. et al. (2018), "Mobile applications for accessible tourism: overview, challenges and a proposed platform", Information Technology \& Tourism, 19 (1-4), pp. 29-59.

Rong, J. et al. (2012), "A behavioral analysis of web sharers and browsers in Hong Kong using targeted association rule mining", Tourism Management, 33 (4), pp. 731-740.

San Martín, H. and Herrero, Á. (2012), "Influence of the user's psychological factors on the online purchase intention in rural tourism: Integrating innovativeness to the UTAUT framework", Tourism Management, 33 (2), pp. 341-350.

Shi, Y. (2006), "The accessibility of Queensland visitor information centres' websites", Tourism Management, 27 (5), pp. 829-841.

Siguaw, J. A. et al. (2000), "Adoption of information technology in US hotels: strategically driven objectives", Journal of travel Research, 39 (2), pp. 192-201.

Sox, C. B. et al. (2016), "Technology use within meetings: a generational perspective", Journal of Hospitality and Tourism Technology, 7 (2), pp. 158-181.

Spencer, A. J. et al. (2012), "A hierarchical model of technology adoption for small owner-managed travel firms: An organizational decision-making and leadership perspective", Tourism management, 33 (5), pp. 1195-1208.

Stepchenkova, S. and Zhan, F. (2013), "Visual destination images of Peru: Comparative content analysis of DMO and user-generated photography", Tourism Management, 36 590-601.

Straker, K. and Wrigley, C. (2016), "Translating emotional insights into digital channel designs: Opportunities to enhance the airport experience", Journal of Hospitality and Tourism Technology, 7 (2), pp. 135-157.

Straub, D. (2012), "Editor's comments: does MIS have native theories?", MIS quarterly, 36 (2), pp. iii-xii.

Straub, D. and del Guidice, M. (2012), "Editor's Comments: Use", MIS Quarterly, 36 (4), pp. iii-viii.

Susskind, A. M. et al. (2003), "To look or book: An examination of consumers' apprehensiveness toward Internet use", Journal of Travel Research, 41 (3), pp. 256-264.

Tajeddini, K. and Trueman, M. (2014), "Perceptions of innovativeness among Iranian hotel managers", Journal of Hospitality and Tourism Technology, 5 (1), pp. 62-77. 
Tatar, Ş. B. and Eren-Erdoğmuş, İ. (2016), "The effect of social media marketing on brand trust and brand loyalty for hotels", Information Technology \& Tourism, 16 (3), pp. 249-263.

tom Dieck, M. C. et al. (2016), "Mapping requirements for the wearable smart glasses augmented reality museum application", Journal of Hospitality and Tourism Technology, 7 (3), pp. 230253.

Tsai, H.-T. et al. (2005), "Emerging e-commerce development model for Taiwanese travel agencies", Tourism Management, 26 (5), pp. 787-796.

Tseng, C. et al. (2015), "Travel blogs on China as a destination image formation agent: A qualitative analysis using Leximancer", Tourism Management, 46 347-358.

Tussyadiah, I. P. and Fesenmaier, D. R. (2009), "Mediating tourist experiences: Access to places via shared videos", Annals of Tourism Research, 36 (1), pp. 24-40.

Venkatesh, V. et al. (2003), "User acceptance of information technology: Toward a unified view", MIS quarterly, 425-478.

Vogt, C. A. (2011), "Customer relationship management in tourism: Management needs and research applications", Journal of Travel Research, 50 (4), pp. 356-364.

Wang, D. et al. (2014), "Adapting to the mobile world: A model of smartphone use", Annals of Tourism Research, 48 11-26.

Wang, Y.-S. et al. (2016), "Factors affecting hotels' adoption of mobile reservation systems: A technology-organization-environment framework", Tourism Management, 53 163-172.

Wendy Zhu, W. and Morosan, C. (2014), "An empirical examination of guests' adoption of interactive mobile technologies in hotels: Revisiting cognitive absorption, playfulness, and security", Journal of Hospitality and Tourism Technology, 5 (1), pp. 78-94.

Werthner, H. et al. (2015), "Future research issues in IT and tourism", Information Technology \& Tourism, 15 (1), pp. 1-15.

Woeber, K. and Gretzel, U. (2000), "Tourism managers' adoption of marketing decision support systems", Journal of Travel Research, 39 (2), pp. 172-181.

Wozniak, T. et al. (2017), "The return on tourism organizations' social media investments: preliminary evidence from Belgium, France, and Switzerland", Information Technology \& Tourism, 17 (1), pp. 75-100.

Xiang, Z. et al. (2009), "Semantic representation of tourism on the Internet", Journal of Travel Research, 47 (4), pp. 440-453.

Xiang, Z. et al. (2015), "Adapting to the internet: trends in travelers' use of the web for trip planning", Journal of Travel Research, 54 (4), pp. 511-527.

Xiang, Z. et al. (2008), "Representation of the online tourism domain in search engines", Journal of Travel Research, 47 (2), pp. 137-150.

Young Chung, J. et al. (2011), "Influence of interactive thematic maps on tourist perceptions: a network analysis", Journal of Hospitality and Tourism Technology, 2 (3), pp. 216-234.

Young Im, J. and Hancer, M. (2014), "Shaping travelers' attitude toward travel mobile applications", Journal of Hospitality and Tourism Technology, 5 (2), pp. 177-193.

Yuan, Y.-L. et al. (2003), "Internet Technology Use by American Convention and Visitors Bureaus", Journal of Travel Research, 41 (3), pp. 240-255.

Yuan, Y.-L. et al. (2006), "The role of information technology use in American convention and visitors bureaus", Tourism Management, 27 (2), pp. 326-341.

Zhang, L. et al. (2014), "The effect of power and gender on technology acceptance", Journal of Hospitality and Tourism Technology, 5 (3), pp. 299-314.

Zhang, T. et al. (2015), "Motivations for customer engagement in online co-innovation communities (OCCs) A conceptual framework", Journal of Hospitality and Tourism Technology, 6 (3), pp. 311-328.

Zheng, W. et al. (2017), "Understanding the tourist mobility using GPS: Where is the next place?", Tourism Management, 59 267-280. 


\section{Appendix}

$<<$ Table 2 to appear about here $>>$ 


\begin{tabular}{|l|l|}
\hline Journal & Downloaded \\
\hline JTR & 52 \\
\hline TM & 98 \\
\hline ATR & 26 \\
\hline JST & 31 \\
\hline JHTT & 76 \\
\hline ITT & 31 \\
\hline Total & 314 \\
\hline
\end{tabular}

Table 1: number of papers downloaded 


\begin{tabular}{|c|c|c|c|}
\hline Keyword & No & Keyword & No \\
\hline \multicolumn{4}{|l|}{ From Barki et al. (1993) } \\
\hline Competitive use of IS & 67 & Executive requirements for decision support & 1 \\
\hline Strategic IS & 39 & User expectations & 15 \\
\hline Competitive IS & 24 & User job titles & 0 \\
\hline Office automation & 1 & CEO & 0 \\
\hline Word processing & 0 & Executive & 0 \\
\hline Satellite work center & 0 & Middle manager & 0 \\
\hline End-user computing & 1 & Senior management & 0 \\
\hline End-user programming & 0 & Entry-level personnel & 0 \\
\hline Operational computing & 1 & Type of IS support & 13 \\
\hline Telecommuting & 0 & Corporate support & 2 \\
\hline Distributed work arrangements & 0 & Departmental support & 0 \\
\hline Users & 122 & Personal support & 2 \\
\hline Individual characteristics & 9 & User support & 5 \\
\hline User attitudes & 15 & Interpersonal support & 0 \\
\hline User behaviour & 56 & Management support & 3 \\
\hline User types & 12 & Type of is access & 0 \\
\hline Direct users & 3 & Direct access & 0 \\
\hline Indirect users & 0 & Chauffeured access & 0 \\
\hline Intermediate users & 0 & Type of processing & 55 \\
\hline End users & 1 & Online IS & 37 \\
\hline Expert users & 2 & Batch IS & 0 \\
\hline Novice users & 0 & Real-time IS & 6 \\
\hline User requirements & 5 & Interactive IS & 12 \\
\hline \multicolumn{4}{|c|}{ From Burton-Jones et al. (2017) } \\
\hline Use & 0 & Routinization & 0 \\
\hline Utilize & 0 & Implementation & 6 \\
\hline Usage & 6 & Adoption & 28 \\
\hline Utilization & 2 & 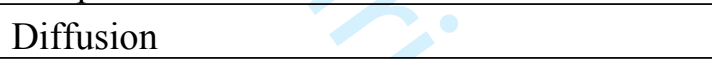 & 2 \\
\hline Appropriation & 1 & Acceptance & 16 \\
\hline Adapt & 0 & Continuance & 0 \\
\hline Assimilation & 0 & Addiction & 0 \\
\hline Infusion & 0 & Trying & 0 \\
\hline
\end{tabular}

Table 2: keywords used, and the number of papers coded 

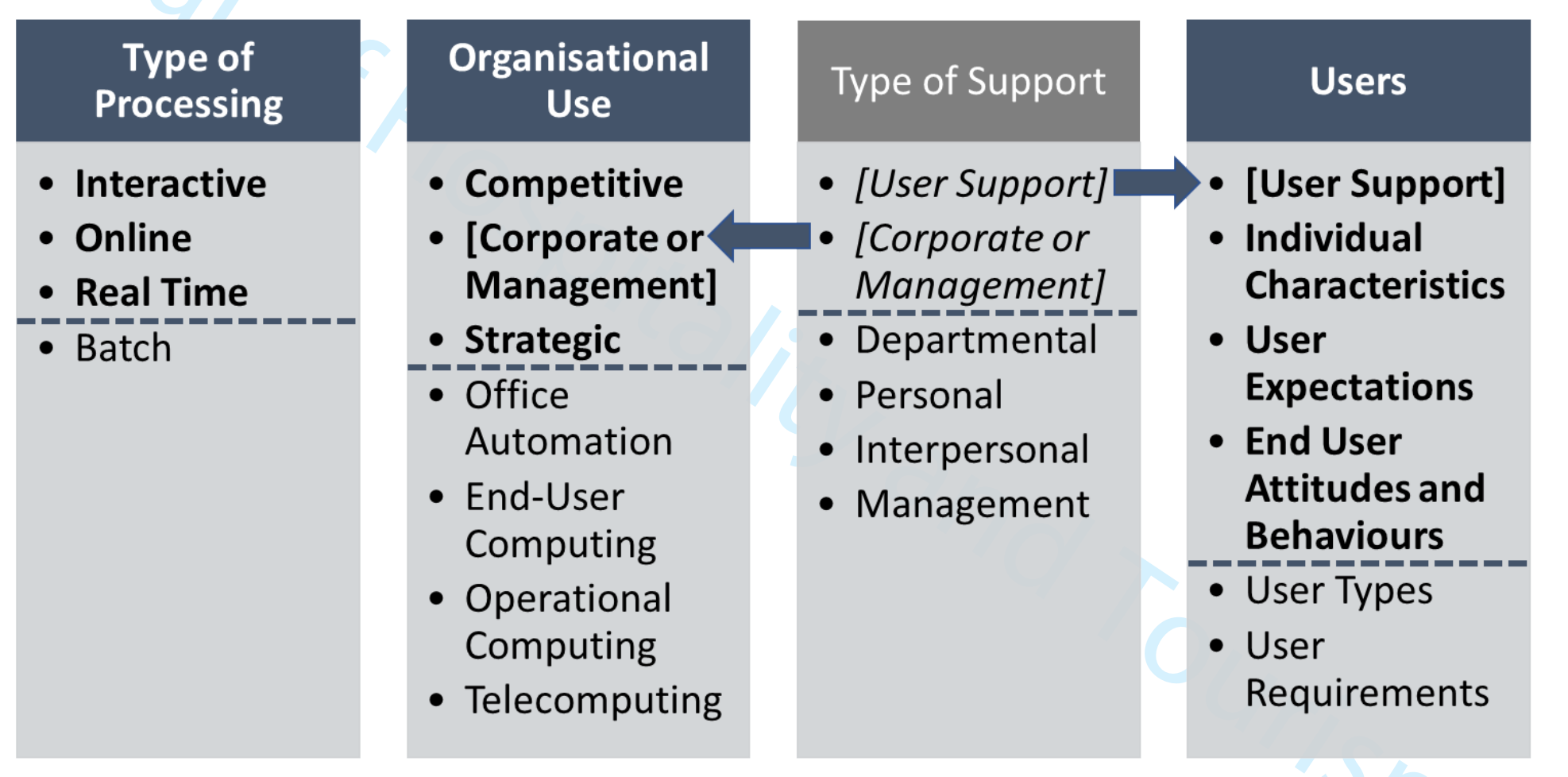

\section{Type of Access}

- [User Support]

- Individual Characteristics

- Direct Access

- Chauffeured Access

- User Expectations

- End User Attitudes and Behaviours

- User Types

- User Requirements

Figure 1: Findings 